\title{
ESTUDIOS
}

\section{Borges: el elogio de la sombra ${ }^{*}$}

A partir de 1958, la actividad poética de Borges se intensifica sensiblemente y aún llega a ser central en su labor creadora. Si es verdad que aún Borges escribe poemas dentro de una métrica tradicional, especialmente sonetos (nada neoclásicos, como podría pretender cierta crítica; escritos, más bien, con cierta desenvoltura, en un estilo que pocas veces pierde el tono coloquial), la forma que tiende a ser dominante en sus nuevos poemas es el verso libre, incorporando una vez más el versículo, combinando también lo narrativo y lo anecdótico. Se trata, en gran medida, de una poesía de lector, pero del vasto lector que ha sido Borges. Y la experiencia estética de Borges ¿no es, acaso, tan inquietante y compleja como cualquier experiencia directa (si la hay) del mundo? ¿No es también la lectura una manera de soñar el mundo? El propio Borges lo ha sugerido así desde el comienzo mismo de su obra. En uno de sus poemas de los años sesenta, evoca la historia del Quijote y conjetura que este caballero del "heroico afán" en verdad "no salió nunca de su biblioteca"; así, fue él mismo y no Cervantes, quien soñó su crónica de aventura y esta "no es más que una crónica de sueños". Esa ha sido su propia suerte, añade Borges. Y concluye: "Sé que hay algo / Inmortal y esencial que he sepultado / En esa biblioteca del pasado / En que leí la historia del hidalgo". Y en uno de los poemas de su último libro, llega a formular esta misma idea de manera casi paradigmática, resumiendo todo el

* Este texto es un capítulo del libro que sobre Borges publicará próximamente Editions Seghers en su colección Poètes d"Aujourd"but. Aunque da una visión de la poesía de Borges a partir de 1958, su análisis se centra especialmente en su último libro, Elogio de la sombra (Emecé, Buenos Aires, 1969). 
sentido de su obra. En ese poema dice: "Que otros se jacten de las páginas que han escrito; / a mí me enorgullecen las que he leído".

Es posible que este rasgo pueda verse (quizá Borges mismo lo aceptaría así) como una limitación; en un sentido más profundo, es igualmente una manera de hacer de la literatura, de la tradición, de Io ya escrito una suerte de palimsesto, esa página incesante donde todos escriben y teescriben el mundo. Pero, ádemás, en sus nuevos poemas, Borges rescata muchos de los temas de su ptimera poesía (Buenos Aires, la pampa, los antepasados, los gauchos, los compadritos) y aún escribe letras de bailes populares como la milonga. Así, en su biblioteca babélica toma sitio su mundo criollo, que Borges vuelve cada vez más mitológico, al que corrige también desde un futuro que no quiere ser clarividente y que es tan enigmático como el pasado. Escribe, por ejemplo, un poema que lleva este largo título: "Líneas que pude haber escrito y perdido en 1922". En él evoca los ocasos, los arrabales últimos, las albas ruinosas, los negros jardines en la lluvia, los libros; pero habla también de "la mutua noche" (aludiendo a su ceguera), de Walt Whitman ("cuyo nombre es el universo"), de los sajones, los árabes y los godos ("que, sin saberlo, me engendraron"). Al final se pregunta: "isoy yo esas cosas y las otras / o son llaves secretas y arduas álgebras / de lo que no sabremos nunca?" Es decir, puesto a escribir desde su pasado con la experiencia se su vida posterior, Borges no logra discernir la clave de sus años: su coriección del pasado es una nueva invención, un nuevo enigma. En otro de sus nuevos poemas dirá: "el presente ya es el porvenir y el olvido". Esta suerte de paradoja no es sino una manera más compleja de vivir el tiempo: el tiempo como una dialéctica incesante entre la memoria y el olvido. Es esta dialéctica, lo veremos, la que rige toda su poesía más reciente.

Si Borges impone límites a su poesía es quizá porque ya él mismo escribe, no desde una situación límite (ello parecería excesivamente patético), sino desde los límites de su propia experiencia, de su vida. Desde tal perspectiva, vivir es sobre todo rememorarse. Así, Borges escribe un poema sobre su destino; ese destino que, de alguna manera, ha sido la sabiduría o el conocimiento, un largo viaje por el universo ("haber navegado por los diversos mares del mundo"; "haber regresado, al cabo de cambiantes generaciones, / a las antiguas tierras de su estirpe"; "haber visto las cosas que ven los hombres") y que concluye, sin embargo, en la ignorancia o en el desamparo: "no haber visto nada o casi nada / sino el rostro de una muchacha de Buenos Aires, 
/ un rostro que no quiere que lo recuerde". El poema es, en realidad, tal como se titula, una elegía. Y Borges se ve a sí mismo no como el otro, sino desde el otro: "Oh destino de Borges, / tal vez no más extraño que el tuyo". Es el mismo sentido que encontramos en el dístico que, con el título (en francés) de "Le Regret d'Heraclite", y que Borges adscribe a uno de sus poetas apócrifos, cierra, como un epitafio, su Obra poética: "Yo, que tantos hombres he sido, no he sido nunca / Aquel en cuyo abrazo desfallecía Matilde Urbach". Esta lucidez en el desamparo o en la desdicha, no lo abandona. Cada acto de su vida se redobla de esta misma evidencia final. En otro poema compara su destino ("hecho de zozobra, de amor y de vanas vicisitudes") con el de una moneda que arroja en un puerto y que llegará al abismo y hasta los más remotos mares. En ese símil, intuye, hay dos series infinitas y paralelas: a cada instante de su vida corresponderá otro de "la ciega moneda". Pero mientras en su sueño o en su vigilia nunca podrá liberarse de la conciencia del tiempo y su laberinto, siente que el viaje de la moneda es ajeno a esa conciencia. Acaso, sugiere, hay una forma no sólo de libertad, sino también de plenitud, en esa ignorancia. En todo caso, es esta ignorancia lo que Borges busca en su pasado. Un poema como "Alguien" (título que también sugiere nadie) es aún más revelador en este sentido. En él Borges se ve a sí mismo como "una hombre trabajado por el tiempo" y que, quizá por ello mismo, "ni siquiera espera la muerte", pero que en lo más trivial de su ritual cotidiano ("al cruzar la calle") siente "una misteriosa felicidad"; esa felicidad le viene no "del lado de la esperanza / sino de una antigua inocencia, / de su propia raíz o de un dios disperso." La ignorancia que busca Borges es esa inocencia. O mejor: lo que propone Borges es el regreso no sólo a su pasado sino a su prpio origen, a esa dimensión donde la evocación se identifica con la invención, donde la memoria se nutre del olvido; más aún: donde el olvido es el no-ser que es una forma del ser. Por ello, al final del poema, Borges intuye que esa inocencia (la "indescifrable taiz") no surgirá sino en la muerte; la muerte, no como negación, sino como verdadera rerelación de la identidad del tiempo. Así, escribe:

Quizá en la muerte para siempre seremos, cuando el polvo sea polvo, esa indescifrable raíz, de la cual para siempre crecerá, 
ecuánime $o$ atroz, nuestro solitario cielo o infierno.

La meditación de Borges sobre su pasado es, en el fondo, una meditación sobre la muerte. Y quizá ella encuentra verdadera coherencia en su último libro Elogio de la sombra. "A mis años toda empresa es una aventura / que linda con la noche", dice en uno de sus poemas. Esa noche es la muerte, pero la muerte como iluminación. Por ello, al final del último poema (lleva igual título) de este libro, Borges dice haber llegado a su centro, a su álgebra y a su clave, a su espejo. $Y$ luego, con serena convicción, concluye: "Pronto sabré quién soy". Es la reiterada convicción de un poema de años un poco anteriores, en el que al interrogante final sucedía la intuición de su destino: "¿Quién es el mar, quién soy? Lo sabré el día / Ulterior que sucede a la agonía".

Pero uno de los temas dominantes en la obra de Borges ha sido, por el contrario, la certeza de que todo hombre siempre ignora quién es. El saber que ahora espera, debemos pensar, es la revelación de la muerte -quizás, mejor, la muerte como revelación. De alguna manera es también la experiencia de aquel Francisco Laprida que, antes de morir, descubre jubiloso su "destino sudamericano" en medio de la pampa bárbara ("Poema conjetural"). Pero tal vez debamos pensar también que para Borges esta experiencia última es como una sabiduría más amplia, de la que se nutre justamente su libro más reciente. Esa sabiduría implica que si el destino del hombre es finalmente la muerte, ese destino abarca, en realidad, toda su vida, y aún la modifica. Formulada en futuro, como lo hace Borges, nos remite más bien a un pasado, un pasado cambiante y también indescifrable. Así, la lectura del libro debería empezar a partir de este poema último. Este poema cierra el libro, pero abre un interrogante sobre el sentido total de la obra de Borges; de igual modo, podria cerrar su vida, pero nos convoca a pensar en todo su decurso.

Aparentemente, la lectura que proponemos habría de ser doble: la de los poemas y la de la existencia de quien los ha escrito. Pero sabe. mos que, en el fondo, no se trata sino de una sola y única lectura posible. Poesía y vida se entrelazan una vez más en Borges: ambas participan de una misma fuerza imaginaria. Así también lo que parece postular Borges es que el sentido de la más alta poesía es el de prefigurar un destino. Lo que ya sabíamos: es lo que sugiere toda su obra anterior. ¿Habría que citar el admirable epilogo de El bacedor? Allí 
Borges ha escrito: "Un hombre se propone la tarea de dibujar el mundo. A lo largo de los años puebla un espacio con imágenes de provincias, de reinos, de montañas, de bahías, de naves, de peces, de habitaciones, de instrumentos, de astros, de caballos y de personas. Poco antes de morir, descubre que ese paciente laberinto de lineas traza la imagen de su cara". ¿Y no es en cierto modo lo mismo que nos ha dicho en su "Arte poética?" Este nuevo libro, ahora, tiende no ya tan sólo a confirmar, sino a hacer real esa intuición.

La muerte es ahora para Borges una suerte de iluminación en tanto revela el sentido de una vida. La relación entre muerte y vida ¿no es entonces la misma que entre obra y creador? De ahi que Borges no se sienta vulnerado por la muerte. Tampoco busca afanosamente el sentido (¿el de su vida, el de su obra?) que ella le deparará. Borges, simplemente, lo espera; la espera es una de las formas de la fatalidad. "Seguro de mi vida y de mi muerte, miro los ambiciosos / y quisiera entenderlos", había escrito en uno de los poemas de su juventud. De alguna manera ahora también asume esa jactancia de quietud, título de aquel poema. Como en la dialéctica de otros tantos contrarios que aparecen en su obra, la quietud es nuevamente una forma de posesión. El poema "Elogio de la sombra" es la mą́s conmovida aceptación de la vejez ("puede ser el tiempo de nuestra dicha"), del despojo del tiempo y de la ceguera ("Siempre en mi vida fueron demasiadas las cosas; / Demócrito de Abdera se arrancó los ojos para pensar; / el tiempo ha sido mi Demócrito"). Y aún ante la progresiva pérdida del mundo, escribe: "Todo esto debería atemorizarme / pero es una dulzura, un regreso". En un poema de 1964 (lleva, incluso, esta fecha como título), había escrito: "Lo que era todo tiene que ser nada". En poema de este nuevo libro -llega a expresar esa idea pero a través de un deseo radical y profundo: "Quiero morir del todo; quiero morir con este compañero, / mi cuerpo". Morir del todo es la forma más irrevocable de dejar de ser. Pero ¿quién no recuerda que para Borges dejar de ser o ser nada es quizá un modo más singular de plenitud? Así como el olvido es también la posibilidad de una más recóndita presencia. "Espero que el olvido no se demore", escribe en ese mismo poema en que anhela la muerte. $Y$ en otro nos dice que el olvido "es una posesión, porque el olvido / es una de las formas de la memoria, su vago sótano, / la otra cara secreta de la moneda". En un poema anterior, de los años sesenta, Borges se muestra incluso más radical: Ese poema es una meditación sobre la muerte, en el que, al final, se condensa una de las más extrañas visiones y aspiraciones 
de Borges: "Quiero beber su cristalino Olvido, / Ser para siempre; pero no haber sido". La muerte se presenta, así, como una transparencia en la que todo se borra $y$, sin embargo, todo adquiere un nuevo rostro: el de la permanencia. Se trata, pues, de una voluntad no sólo de morir, sino de ser olvidado, y aun de olvidarse. Borges está y no está en el mundo; su vida está y no está en el recuerdo. En uno de sus ensayos de Discusión, Borges ha reivindicado a los gnósticos y sugerido que de haber triunfado sus doctrinas otro sería el sentido de nuestra historia; en los libros canónicos, añade, se inscribirían frases fulminantes como la de Novalis: "La vida es una enfermedad del espíritu", o como la de Rimbaud (de tantas consecuencias en el pensamiento poético contemporáneo; en los surrealistas, por ejemplo): "La vraic vie est absente. Nous ne sommes pas au monde". Borges no sólo ha intuido también esa otra dimensión del espíritu; su poesía actual es un intento por acceder a ella. $\mathrm{Y}$ esa dimensión quizá sea para él la inocencia.

La muerte es ciertamente para Borges un regreso y un reencuentro; quizá también la verdad. La vida, en cambio, es ilusoria; pero ilusoria, no simplemente vana. La vida y el mundo mismo son ilusorios porque son laberintos en los que nos perdemos sin vislumbrar nuestra identidad, nuestra imagen verdadera. Borges ya lo ha dicho en textos memorables como el ensayo "El espejo de los enigmas". Aun lo ha desarrollado poéticamente en una de sus parábolas de El bacedor, titulada "Everything and nothing", figuración del destino de Shakespeare, así como en uno de sus relatos más sobrecogedores. "Las ruinas circulares". En varios pasajes de Elogio de la sombra, reitera la misma intuición, la misma experiencia. "Sentí, como otras veces, la tristeza de comprender que somos como un sueño", escribe. $Y$ en otros poemas, observa: "Han cambiado las formas de mi sueño", ante el paisaje de Cambridge; "Vivieron su destino como en un sueño, sin saber quiénes eran / o qué eran", al evocar a los gauchos; "Vivió matando y huyendo. / Vivió como si soñara", al resumir la historia de uno de los personajes de sus milongas.

Al comienzo de Aurélia, se dice: "Le rêve est un seconde vie". Este sentido del sueño en Nerval y luego también en el surrealismo, no parece exactamente el mismo que en Borges. Para Nerval y los sutrealistas el sueño asume los plenos poderes de la imaginación; es como la realidad privilegiada. Aunque no es ajeno a este sentido, Borges siente que el sueño es una forma del laberinto y de la continua perplejidad de la existencia. Escribir es, también para él, una actividad 
onírica, pero en una aceptación más inocente que en los surrealistas y, por supuesto, sin los métodos que éstos invocan. Recuerda que Jung (uno de los pocos psicólogos modernos que parece estimar) equiparaba la literatura a los sueños. En otra ocasión ha escrito: "Toda poesía es misteriosa; nadie sabe del todo lo que le ha sido dado escribir". Idea que reafirma en el prólogo de este nuevo libro: "La poesía no es menos misteriosa que los otros elementos del orbe. Tal o cual verso alortunado no puede envanecernos, porque es del Azar o del Espíritu; sólo los errores son nuestros". Declara también, en ese prólogo, no tener una estética, sino algunas astucias que le ha enseñado el tiempo (lo que es igualmente una astucia y una forma más de su ironía). Aún más, dice no creer en las estéticas. "En general --escribe- no pasan de ser abstracciones inútiles; varían para cada escritor $\mathrm{y}$ aun para cada cada texto y no pueden ser otra cosa que estímulos o instrumentos ocasionales".

"Ningún hombre sabe quién es". El sentido de esta frase de Léon Bloy es uno de los temas esenciales, ya lo hemos dicho, de la obra borgiana. Ahora, sin embargo, Borges tiene la esperanza de saber quién es él. Ha vivido su vida como en un sueño- y también en una espantosa vigilia. Ahora cree despertar. Lo que él es se (nos) lo revelará la muerte, pero sobre todo, claro está, su propia obra. La aventura mortal se hace vital y se confunde así con la poética. Son, en verdad, una sola aventura, y es ahora cuando empieza. Por ello este libro es un elogio de la sombra; la sombra como un variado símbolo: la ceguera, la vejez y el presentimiento de la muerte, pero también, y sobre todo, la verdadera iluminación. Ese elogio es igualmente un elogio del munco: un mundo visto por un hombre a la vez vulnerado y sereno, perplejo y también dichoso. Ese elogio es una sabiduría o el comienzo de una sabiduría. A través de ella alcanzará Borges su auténtica persona, creada e inventada por su obra. Esa persona borgiana es también, como a él le gustaría decirlo, muchos y nadie ("Mi nombre es alguien y cualquiera", escribió en uno de sus primeros poemas). Pero es sobre todo la que nace de su obra. Lo que él mismo ha sugerido en otro texto ("Borges y yo") que ya hemos comentado. Aunque intuye incluso que las páginas válidas de "Borges" no podrán salvarlo, final_ mente reconoce: "Yo he de quedar en Borges, no en mí (si es que alguien soy)". ¿Borges criatura mortal y a la vez persona inmortal? ¿Creerá de verdad en ello? Quizá sí, pero no sólo dudándolo sino asumiendo el riesgo que ello implica. "Qué morirá conmigo cuando yo muera, qué forma patética o deleznable perderá el mundo?", se pre- 
gunta en uno de los textos de El hacedor. En otro de ese mismo libro, afirma que "no hay en la tierra una sola cosa que el olvido no borre o que la memoria no altere y (..) nadie sabe en qué imágenes lo traducirá el porvenir". Pero la secreta voluntad de Borges es la de permanecer en la palabra poética. En uno de sus poemas de los años sesenta, expresa esa voluntad: "Pido a mis dioses o a la suma del tiem. po / Que mis días merezcan el olvido / Que mi nombre sea Nadie como el de Ulises, / Pero que algún verso perdure / En la noche propicia a la memoria / $\mathrm{O}$ en la mañana de los hombres". Borges intuye, sin embargo, que su poesía misma es una aventura y un riesgo: no le pertenece del todo, se le escapa, está sometida al tiempo. Tal vez debamos leer este nuevo libro como la última manifestación de ese riesgo.

Elogio de la sombra es una fragmentada y hasta desordenada suma del universo borgiano. Están en él: los laberintos, los espejos, la soledad, el amor, el tiempo, la historia, la memoria, los antepasados, los amigos muertos, los gauchos, los compadritos, Buenos Aires, Inglaterra, la Biblia, Whitman ("cuyo gran eco ojalá reverbere" en estas páginas), De Quincey ("padre de las palabras que no se olvidan"), las bibliotecas, los viajes (en el espacio y en el tiempo), la ceguera. Todo lo que ha dado un sentido mitológico a ese universo. Nada nuevo aparentemente (acaso el lector encontrará, como lo propone el propio Borges, dos temas nuevos:: la vejez y la ética). Pero nos enfrentamos a ese universo bajo una luz distinta y hasta más intensa: sentimos, como pocas veces, la presencia inmediata y retrospectiva de un hombre que al llegar al término de su destino intuye que también lo empieza. "His end and his beginning" es el título de una de las parábolas de este libro. Después de morir, un hombre cree seguir viviendo: estaba aún soñando. Cumple con sus tareas cotidianas y lee sus libros habituales. Dentro del sueño siente una pesadilla: rostros, seres y cosas empiezan a borrarse y a dejarlo. No sospechó la verdad, sino que ésta lo iluminó de pronto. Comprendió que ya no podía recordar; ya no había recuerdos, ni formas, ni sueños. Estos "eran su realidad, una realidad más allá del silencio y de la visión $y$, por consiguiente, de la memoria". Esta evidencia lo lleva a aceptar su destino $y$, desde otra lucidez, comienza su largo viaje. "De algún modo sintió que su deber era dejar atrás esas cosas; ahora pertenecía a este nuevo mundo, ajeno de pasado, de presente y de porvenir. Poco a poco este mundo lo circundó. Padeció muchas agonías, atravesó regiones de desesperación y de soledad. Esas peregrinaciones eran atroces porque tras- 
cendían todas sus anteriores percepciones, memorias y esperanzas. Todo el horror yacía en su novedad y esplendor. Había merecido la gracia, desde su muerte había estado siempre en el cielo". Este viaje en la postvida, en el vacío, es también una aventura - dolorosa, pero serenamente asumida - hacia el ser, hacia un nuevo éxtasis y una nueva plenitud. Una suerte de mística se transparenta en esta dialéctica borgiana. Más que parábola o símbolo, textos como éste sobrecogen porque son verdaderas visiones. Si el pasado es irreal o ilusorio (perdido "en lús reinos espectrales de la memoria"), el futuro -esa larga peregrinación que nos ha descrito- se hace visible. Pero, además, pasado y futuro se tocan, se iluminan recíprocamente. Lo que es se torna en lo que fue, pero lo que fue se torna en lo que será, e inversamente. Esta dialéctica de los tiempos vale para la existencia y para la obra misma; de igual modo, ésta se sumerge en la aventura de la muerte, una continua correspondencia entre el olvido y la memoria.

El más perfecto laberinto ha sido para Borges una línea recta. Esa línea se convierte ahora en un círculo, que se cierra y se abre de nuevo, e incesantemente. El secreto de Borges quizá sea (como dijo de Carriego, proyectándose más bien él) el "sentido de inclusión y de círculo" que hay en su existencia. Borges no sólo reescribe lo ya escrito, reescribe también su propia obra; no sólo evoca su vida, evoca igualmente su propia evocación, interpola otra memoria dentro de su memoria misma. Su fuerza reside en estas recurrencias y repeticiones. Así, el laberinto es uno de los temas que suyace en todo el desarrollo de Elogio de la sombra; aparece, además, como tema esencial en dos poemas. Uno de ellos se titula "El laberinto"; el otro, simplemente "Laberinto". El artículo que define al primero y el tratamiento mismo del tema, nos figuran el laberinto mítico del minotauro. Es como la transposición poética de uno de sus cuentos, " $\mathrm{La}$ casa de Asterión". Como en el relato, Borges nos presenta al minotauro narran. do su propia vida ("sigo el odiado / camino de monótonas paredes / que es mi destino"), pero sin saber exactamente quién es él ("El aire me ha traído / en las cóncavas tardes un bramido / o el eco de un bramido desolado", dice de manera patética). Intuye, sí, la presencia de su perseguidor (el Otro) y aun su muerte, pero este destino final lo siente más bien como un anhelado desenlace. "Nos buscamos los dos. Ojalá fuera / éste el último día de la espera", dice al final. Como en el relato, Borges concentra en este poema múltiples significaciones; en él, sin embargo, hay una que no aparece en aquél. Es la imagen del laberinto que ahora nos da; el laberinto son "rectas galerías / 
que se curvan en círculos secretos / al cabo de los años". Es decir, el laberinto se convierte en círculo por obra del tiempo, y la muette parece cerrarlo. También lo abre. Ese círculo es de alguna manera infinito, sólo que un infinito quizá distinto ahora: su progresión es concebible a partir de la muerte, es movimiento hacia el origen. En el otro poema, el laberinto es todo el universo y no deja de ser revelador que la persona que habla en él es un yo que se desdobla en un tú. Dice: "No habrá nunca una puerta. Estás adentro / y el alcázar abarca el universo / $\mathrm{Y}$ no tiene ni anverso ni reverso / $\mathrm{Ni}$ externo muro ni secreto centro". El laberinto es el universo y el caos. Adèmás, ya no hay en él monstruos: "No existe. Nada esperes. Ni siquiera /En el negro crepúsculo la fiera". Mientras en el primer poema la muerte es un final deseado y hasta una liberación, en éste ni siquiera la muerte existe: el laberinto es perpetuo y lo abarca y domina todo. Esta dualidad y paradoja no debe asombrar: la obra de Borges encarna siempre una doble naturaleza, un doble movimiento. (En cierta medida, Borges aún sigue fiel a aquel principio de la literatura de "Tlön" sobre el libro que encierra su contralibro, su réplica). Pero quizá ahora tiende a una posible fusión o coherencia: la muerte restituye el orden en el universo dado que cumple con una clave secreta. Es decir, la vida (el laberinto) adquiere sentido a partir de la muerte misma (¿no decía también Malraux que la muerte convierte a la vida en destino?) Así, a partir de su prevista muerte, Borges evoca en este libro su propia vida. En esta evocación se mezclan lo íntimo y lo impersonal; la estricta aventura del Borges que se desplaza —es verdad que como en sueño- desde Buenos Aires hasta Cambridge a Texas, pero también la otra aventura que de algún modo es memorable y aun ancestral: la de los libros, de la historia, la de la cultura. En otras palabras, la aventura de un hombre que es igualmente muchos hombres (y ninguno).

De ahí que uno de los grandes temas de este libro sea el de la memoria. "Esa moneda que nunca es la misma", dice el primer poema. Iste poema tiene también un sentido dominante en el libro. La persona aue en él habla es Cristo, según uno de los versículos de San Juan (el Verbo hecho carne). $Y$ en uno de los pasajes esenciales del poema, dice:

He encomendado esta escritura a un hombre cualquiera;

no será nunca lo que quiero decir,

no dejará de ser su reflejo.

Desde Mi eternidad caen estos signos.

Que otro, no el que ahora es su amanuense, escriba el poema. 
Este poema es dominante porque lo que en él se propone es la idea del Libro o del Poema que encierre el secreto o el orden del universo. Una vez más, Borges asume la tentativa de gran parte de su poesía anterior y de sus relatos (cf. "Mateo XXV", "Parábola del Palacio", "La biblioteca de Babel"). Las frecuentes referencias a la Biblia (el Libro "que es el espejo / De cada rostro que sobre el se inclina"), no invalidan tal tentativa. Es un punto de llegada, pero también de partida. Por ello Borges escribe ahora su "Evangelio apócrifo". En uno de sus recientes poemas (suerte de continuación del "Poema de los dones"), Borges evoca nuevamente su destino en las bibliotecas; está ya ciego y dice:

El hombre que está ciego, sabe que ya no podtá descifrar

Los hermosos volúmenes que maneja

y que no le ayudarán a escribir

El libro que le justificará ante los otros.

Así, la escritura del Libro parece una vez más imposible, pero no por ello Borges deja de concebirla. "Desconocemos - dice en otro texto - los designios del universo, pero sabemos que razonar con lucidez y obrar con justicia es ayudar a esos designios, que no nos serán revelados". Borges entiende que, al menos, su libro no será tan solo expresión de lo personal; de alguna manera se inscribe en un propósito cósmico; igualmente, se nutre de los demás libros ya escritos y que él sigue "leyendo en la memoria, / leyendo y transformando". Si no el libro total y único, Borges nos propone uno en el que los otros se reconozcan. Es decir, propone una forma impersonal de arte: el poema es sólo un objeto; el hecho estético $-\mathrm{y}$ humano- empieza cuando el lector se reconoce en él o cuando se le opone también, transformándolo continuamente.

De esta manera, el tema de la memoria en Borges parece acoger varias significaciones: evocación de un pasado que, en lo esencial, puede concernir a muchos; esa evocación, a su vez, y en gran medida, es una continua invención. La memoria no nos da una realidad o un pasado unívoco, sino ambiguo y quizá múltiple. La memoria es, nos dice Borges, un "quimérico museo de formas inconstantes, / ese montón de espejos rotos". El pasado es, pues, como un mundo fragmen. tado que hay que reconstruir o iluminar. También, además, ese pasado tiene su propia vida: las cosas que lo forman son insensibles a nuestro 
transcurrir. Al evocarlas en otro poema, Borges comprende a través de ellas lo que hay en toda vida de la fatalidad del tiempo: "Durarán más allá de nuestro olvido; / No sabrán nunca que nos hemos ido". Fragmentación, olvido: obras del tiempo. Otro de los temas esenciales, como en toda la obra borgiana, de este libro.

En uno de sus ensayos escrito para refutar el tiempo, Borges ha dicho que nuestro destino es espantoso no por irreal, sino porque es irreversible y de hierro. "El tiempo es la sustancia de que estoy hecho", agrega luego. Es decir, el tiempo no es algo que esté fuera sino dentro de nosotros mismos. En esa frase hay, por supuesto, toda una ambigüedad. "El río me arrebata y soy ese río", dice también en un poema de ahora titulado "Heráclito", retomando la misma concepción y hasta la misma imagen que antes había desarrollado en el ensayo a que aludimos. Pero quizá en el poema tiende a esclarecer la anterior ambigüedad cuando sugiere: "Acaso el manantial está en mí. / Acaso de mi sombra / surgen, fatales e ilusorios, los días". Si el tiempo es irreversible y nos devora (por cllo nuestro destino es de hierro), ¿no es posible también, si el hombre es el manantial del cual fluye, que puede ser sometido a esquemas humanos, aunque estos esquemas sean provisorios, como diría Borges? Así, paralelamente, en este nuevo libro Borges hace una vez más de su poesía una reSutación del tiempo.

En un poema de los años sesenta, Borges comprende que la única posesión del hombre sobre el tiempo es el instante: "El hoy fugaz es tenue y es eterno; / Otro Cielo no esperes, ni otro Infierno". Precéria o no, esa posesión tiene, sin embargo, la virtud de ser continua; la fugacidad y la eternidad se confunden: ambas son tiempo en movimiento. $\mathrm{Y}$ en uno de los poemas que en Elogio de la sombra dedica a James Joyce, se dice al comienzo: "En un día del hombre están los días / del tiempo". En esta frase que condensa con sencillez toda la tentativa creadora de Joyce en "Ulysses", se siente igualmente toda la concepción borgiana de lo que podriamos llamar el éxtasis del ttempo: movimiento que no es sucesión sino superposición y simultaneidad. Perpetuo móvil inmóvil, ese día total no está sometido a un ritmo progresivo sino circular. Así, nos dice Borges, "el ubicuo río del tiempo terrenal" tornará a su fuente, "que es lo Eterno", y se apagará "en el presente, / el futuro, el ayer, lo que ahora es mío". Borges sabe que sólo lo temporal es su dominio, pero no por ello deja de intuir y buscar la eternidad. De ahí que al final de este poema, anhele "coraje y alegría / para escalar la cumbre de este día". Lo que Borges anhela, ciertamente, es el enfrentamiento con la muerte, que es lo 
eterno, pero lo eterno no como abstracción sino como sustancia hecha del tiempo mismo (tal como ya lo había concebido en su Historia de la evernidad). Así, en otro poema, Borges evoca el sucidio de un poeta amigo en 1928. Sobre ese mismo tema había escrito un poema que aparece en Cuaderno San Martín (1929), en el que al despojo de la muerte oponía "los cargados minutos / por los que se salva el honor de la realidad" $y$ en el que, además, figuraba "un sedimento de tternidad, un gusto del mundo", aun cuando el tiempo abandone al hombre. Ahora, casi cuarenta años después (¿no es en cierta manera sobrecogedor?), se vuelve sobre esa muerte en uno de los poemas más lúcidos e intensos de este libro, y no para reiterar la elegía, sino esta vez, para descubrir la intención de esa muerte. Con precisión casi geométrica, y también obsesionante, reconstruye los actos que procedieron al suicidio, como si se desarrollaran según otra presisión: la "disciplina" de la voluntad. Es quizá el tema de la muerte como deliberada conquista de un destino y de la eternidad misma. Por ello Borges dice: "Ahora es invulnerable como los dioses", y también: "Ahora es invulnerable como los muertos". Evocando luego, en otro poema, a Ricardo Güiraldes, lo ve presente entre los amigos conversando "como en el puro sueño de un espejo", y añade: "Tú eres la realidad, yo su reflejo". Así, lo que Borges espera secretamente es ser el espejo mismo, esa última realidad exacta que da la muerte.

El olvido, la muerte, la ausencia: formas de una nueva posesión. En otto poema de Elogio de la sombra, Borges rememora la promesa de un pintor amigo de regalarle un cuadro; el amigo muere antes de cumplir su promesa. Y Borges afirma: "Sólo los dioses pueden prometer, porque son inmortales". Pero luego piensa que de haber tenido el cuadro, éste se habría convertido en una cosa más con el tiempo, habría sido, incluso, un objeto más atado a las vanidades de la casa. La irrealizada promesa, en cambio, le otorga una presencia más profunda del cuadro: una cosa que "ahora es ilimitada, incesante, capaz de cualquier forma y / cualquier color y no atada a ninguno". Así, en esa ausencia, en esa irrealidad, el cuadro estará más presente en él (en Borges, en su memoria de lo no visto) y hasta el fin. Borges concluye: "Gracias, Jorge Larce. / (También los hombres pueden prometer, porque en la promesa / hay algo inmortal)". Lo que recuerda otro texto de Borges que ya hemos citado: "Los hombres inventaron el adiós porque se saben de algún modo inmortales, aunque se juzguen contingentes y efímetos" ( $E l$ bacedor). En este nuevo poema -que significativamente se titula "The unending gift"- vienen a 
condensarse algunos de los grandes temas borgianos: la desposesión como verdadera posesión, la ausencia como signo de otra presencia más invulnerable, lo imaginario como dimensión más reveladora de la realidad. Por ello el universo de Borges es mítico: un universo que se inventa y se justirfica por medio de la palabra. Si el lenguaje de Borges, como todo lenguaje, es "tiempo sucesivo", es igualmente "emblema". Lo es, de igual modo, el mundo real o el espacio intimo que ese lenguaje rememora. Así, por ejemplo, aunque Borges viaje for la geografía siempre sigue existiendo y viéndose en Buenos Aires. Está en otras latides, pero dice: "Buenos Aires, yo sigo caminando / por tus esquinas, sin por qué ni cuándo". Y al evocar especialmente a la ciudad de su fervor, en un largo poema que es una intensa enumeración de todos sus elementos familiares, concluye:

No quiero proseguir; estas cosas son demasiado individuales, son demasiado lo que son, para ser también Buenos Aires.

Buenos Aires es la otra calle, la que no pisé nunca, es el centro secreto de las manzanas, los patios últimos, es lo que las fachadas ocultan, es mi enemigo, si lo tengo, es la persona a quien desagradan mis versos (a mí me desagradan también), es la modesta librería en que acaso entramos y que hemos olvidado, es esa racha de milonga silbada que no reconocemos y que nos toca, es lo que se ha perdido y lo que será, es lo ulterior / lo ajeno, / lo lateral, el barrio que no es tuyo ni mío, lo que ignoramos y queremos.

Aun lo más real, lo que ya forma parte de nuestra intimidad y de nuestra memoria, puede volverse limitado y efímero. La verdadera posesión de Borges es lo que no posee, o lo que ha perdido ("los poseo eis el olvido", dice en otro poema). Su mundo es mítico y tiene un centro en donde todo confluye. Ese centro, de alguna manera, es Buenos Aires, la ciudad conocida y reconocida, pero también la posible, la entrevista, la que acaso lo niega a él mismo. Finalmente, ese centro es todo el universo. Evocando a sus antepasados, gente del campo, de la tierra abierta, Borges dice: "La llanura es ubicua. Los he visto / En Iowa, en el Sur, en tierra hebrea, / En aquel saucedal de Galilea / Que hollaron los humanos pies de Cristo". Por otra parte, si en un día están todos los días del tiempo, para Borges también en un hombre están todos los hombres. Lo que exalta en el judío no es sólo su capacidad de sufrimiento o su voluntad creadora; es sobre todo su fuerza memoriosa, el ser, en cada momento, un símbolo de su estirpe. En un poema que 
titula "Israel", en el que además se afirma un compromiso muy actual, dice:

es Spinoza y el Baal Shem y los cabalistas, un hombre que es el Libro,

una boca que alaba desde el abismo

la justicia del firmamento, un procurador o un dentista que dialogó con Dios en una montaña, un hombre condenado a ser el escarnio, la abominación, el judío, un hombre lapidado, incendiado y ahogado en cámaras letales, un hombre que se obstina en ser inmortal y que ahora ha vuelto a su batalla, a la violenta luz de la victoria. hermoso como un león al mediodia.

De igual modo, esta suerte de panteísmo se revela en la estructura elocutiva de todo el libro. La voz que habla en varios de sus poemas es la de muchos hombres, es una y muchas personas. Borges las crea y se crea a sí mismo a través de ellas; en ellas se distancia y también se reconoce. Aun su propia voz resulta con frecuencia la de otro ("No tit vivido. Quisiera ser otro hombre", dice el Emerson que habla en uno de sus poemas de los años sesenta). Así, Borges ahora llega a escribir los "Fragmentos de un evangelio apócrifo". En ellos están su ética: "Feliz el que no insiste en tener razón, porque nadie la tiene o todos la tienen", "La puerta es la que elige, no el hombre"; su ironía, a veces muy poco piadosa (o evangélica): "No basta ser el último para ser alguna vez el primero"; su incesante dialéctica o su espíritu intencionalmente contradictorio: "Bienaventurados los que no tienen hambre de justicia, porque saben que nuestra suerte, adversa o piadosa, es obra del azar, que es inescrutable" y "Bienaventurados los que padecen persecución por causa de la justicia, porque les importa más la justicia que su destino humano"; "Hacer el bien a tu enemigo puede ser obra de justicia y no es arduo; amarlo, tarea de ángeles y no de hombres" y "Hacer el bien a tu enemigo es el mejor modo de complacer tu vanidad". Hasta llega a expresar una de sus más secretas vocaciones, pero esta vez en una dimensión quizá sobre todo moral y 
que le concierne más personalmente: "Felices los valientes, los que aceptan con ánimo parejo la derrota o las palmas".

En suma, lo que de verdad sugiere Borges en Elogio de la sombra es que la contingencia nos limita por ser lo dado e irreductible; es posiblemente también la falsa posesión, de la que nos libera la muerte. Lo posible, en cambio, es una apertura hacia lo permanente, lo inmortal. La inmortalidad es invención, creación del hombre, que es temporal. El hombre mismo tiene acceso a su más profundo dominio cuando deja de ser él y encuentra su identidad en los otros, en el otro. En otro texto de este libro, Borges esclarece aún más su concepción. "La libertad de mi albedrío - dice- es tal vez ilusoria, pero puedo dar o soñar que doy. Puedo dar el coraje, que no tengo; puedo dar la esperánza, que no está en mí; puedo enseñar la voluntad de aprender lo cuo sé apenas o entreveo".

Pero en el último poema de este libro, Borges cree que pronto habrá de saber quién es él. Esta sabiduría - quizá ahora lo comprendamos mejor - no postula un conocimiento último, una verdad definitiva, sino más bien un reconocimiento a través de una memoria que está más allá de la memoria personal: la nueva invención que aportará la muerte. Por ello dice Borges que a sus años toda empresa linda con la noche; la aventura hacia la muerte y también hacia la vida, la del fin y la de un nuevo comienzo. Pero, además, esa sabiduría que conquistará Borges no puede ser revelada: obviamente morirá con él. La clave de Borges es su clave y el misterio que designa indescifrable. El propio Borges parece sugerirlo lateralmente en uno de los textos en prosa (que también son relatos) de este libro. Es la historia de un joven etnógrafo que acepta la misión de estudiar ciertos ritos esotéricos de las tribus del oeste norteamericano; a su regreso, presentará un informe sobre ese secreto. Después de dos años de perfecta comunión con aquellas tribus, vuelve, pero resuelto a no publicar nada sobre sus estudios y su experiencia. No lo ata ningún juramento, ni la imposibilidad de expresar el secreto en lengua inglesa (podría "enunciarlo de cien modos distintos y aun contradictorios"). El secreto es ciertamente precioso, pero explica: "El secreto, por lo demás, no vale lo que valen los caminos que me condujeron a él. Esos caminos hay que andarlos". Tampoco regresará a la pradera para convivir definitivamente con aquelas tribus, como pudo creer su maestro. "Lo que me enseñaron sus hombres - aclara- vale para cualquier lugar y cualquier circunstancia". Finalmente — narra Borges-, el joven se casó, se divorció "y es ahora uno de los bibliotecarios de Yale". Este destino último, apa- 
rentemente trivial, es también simbólico. El relato, como muchos de El hacedor, es una parábola. No sólo la palabra como silencio o inversamente; igualmente la quietud como una forma más profunda de acción, de posesión o de sabiduría. De la misma manera el secreto de Borges es indecible. El mundo y el arte, aunque impersonales, son aventuras que cada individuo debe vivir radicalmente. $Y$ aun lo que los hace posibles es esa experiencia individual. Es lo que Borges parece proponer también en el poema, que ya hemos comentado en otro capítulo, "Invocación a Joyce". En ese poema, recordamos, Joyce, el verdadero solitario, el desterrado, el hombre dé los "infiernos espléndidos", es el gran símbolo de la aventura creadora del arte contemporáneo. Por ello Borges dice no poder escribir ya "El libro que lo justificará ante los otros". Ese libro es de alguna manera el Libro, pero guedará siempre inconcluso. Cada hombre, cada generación asume incesantemente la tarea de escribirlo o reescribirlo. La muerte lo detiene. Pero la muerte es también un comienzo. Ese libro es circular como el universo. "Le monde, s'il pouvait être exactement traduit et redeublé cn un livre, perdrait tout commencement et toute fin et deviendrait ce volume sphérique, fini et sans limites, que tous les hommes écrivent Et oú ils sent écrits", observa Maurice Blanchot en uno de los ensayos más reveladeros sobre Borges. "La Biblioteca es ilimitada y periódica", concluye el narrador de uno de los cuentos de Borges, después de la fatigante tarea ("Hace ya cuatro siglos") de buscar el libro total en uno de los anaqueles del universo. En cierta manera, es también la misma conclusión de Borges en "Otro poema de los dones", concebido y desarrollado como un largo agradecimiento ("Gracias quiero dar al divino / Laberinto de los efectos y las causas") por lo que le ha sido dado. Hacia el final de ese poema (¿final?), dice:

Por Whitman y Francisco de Asis, que ya escribieron el poema, Por el hecho de que el poema es inagotable

$Y$ se confunde con la suma de las criaturas

$Y$ no llegará jamás al último verso $Y$ varía según los hombres.

En Elogio de la sombra Borges intuye haber llegado a una sabiduria, pero, finalmente, lo que nos propone es un enigma. Este enigma es también una forma de su saber. La mejor experiencia que queda después de leer este libro es la continua perplejidad. Antes de leerlo, quizá sabíamos lo que Borges iba a decir en él. Borges se repite y se reitera, 
Elogio de la sombra es una inmensa tautología borgiana, pero esa tautología modifica toda su obra. Regresamos a Borges y recomenzamos a Borges. También nuestra lectura es circular, sometida a esa inminencia de una revelación que no se produce, con que el propio Borges ha definido el hecho estético.

University of Pittsburgh

GUILLERMO SUCRE 